\title{
SPINAL CORD INJURY
}

\section{Epidemiologycal study of 386 cases with emphasis on those patients admitted more than four hours after the trauma}

\author{
Manoel Baldoino Leal-Filho 1,3, Guilherme Borges², Bruno Ribeiro de Almeida ${ }^{3}$, \\ Aline de Almeida Xavier Aguiar ${ }^{3}$, Marcelo Adriano da Cunha e Silva Vieira ${ }^{3}$, \\ Karoline da Silva Dantas', Ricardo Keyson Paiva de Morais ${ }^{3}$, Carlos Rogério Nogueira dos Santos ${ }^{3}$, \\ Sumihara de Sousa Mendes ${ }^{3}$, Luciana Maria Pinheiro ${ }^{4}$
}

\begin{abstract}
We studied 386 cases of spinal cord injury to analyze the follow up of the patients admitted most of the time more than four hours, the majority of the injuries happening far from the attending health service and first specialized care received long after the accident. This is a clinical study based on data collected during hospitalization of the patients, operated or not, in a Brazilian public health service. The lesion mainly seen was fracture and dislocation, isolated or on multiple levels, and the most important clinical complications were due to respiratory failure and hypotension, especially because $73.8 \%$ were from outside and they were admitted more then four hours after the trauma. The mortality rate was $11.9 \%$, but just $2.1 \%$ had undergone a surgery. The complications resulted in major risk of death when the trauma was at the cervical level and the patients were over 50 years old, especially when admitted more than four hours after the trauma. We emphasize the importance of the first health care concerning the clinical treatment, aiming to reduce the mortality rate.
\end{abstract}

KEY WORDS: spinal cord injury, trauma, spine.

\section{Trauma raquimedular: estudo epidemiológico de 386 casos com ênfase para aqueles pacientes admitidos após quatro horas do trauma}

\begin{abstract}
Resumo - Estudamos 386 casos de trauma raquimedular, observando a evolução dos pacientes admitidos na maioria das vezes após quatro horas do trauma, a maioria procedente de lugar distante do serviço de saúde. Trata-se de um estudo clínico baseado em dados coletados durante a hospitalização, de pacientes operados ou não, em serviço de saúde pública no Brasil. Na maioria das vezes a lesão principal foi fratura-luxação, isolada ou em múltiplos níveis, e as complicações clínicas mais importantes foram devido à insuficiência respiratória e hipotensão, especialmente porque $73.8 \%$ dos casos eram de lugares distantes, tendo sido admitidos mais de quatro horas após o trauma. A taxa de mortalidade foi 11,9\%, sendo 2,1\% em pós-operatório. As complicações resultaram em maior risco de morte quando o trauma foi ao nível cervical, idade acima de 50 anos, especialmente aqueles admitidos com mais de quatro horas. Enfatizamos a importância do primeiro atendimento na admissão, sobretudo para as alterações respiratórias e hemodinâmicas, objetivando reduzir a mortalidade.
\end{abstract}

PALAVRAS-CHAVE: trauma raquimedular, trauma, coluna vertebral.

The traumatic spinal cord lesion is an extremely serious condition that affects mainly the young adult population and it often results in death or disabilities ${ }^{1,2}$. It is considered as an unexpected and catastrophic event, whose consequences persist throughout the patient's life, with influences on the relatives' lives and those of the mem- bers of society ${ }^{3}$. Acute traumatic spinal cord injury results in a critical loss of neurological function below the level of the injury and adversely affects multiple systems within the body, especially the respiratory system. In many countries, spinal cord injury happens at an annual rate from 20 to 40 individuals per million ${ }^{4}$. North America has

${ }^{1} \mathrm{MD}$, PhD, Neurosurgeon, State University of Campinas, São Paulo, Brazil (UNICAMP); ${ }^{2}$ MD, PhD, Neurosurgeon, Professor at UNICAMP; ${ }^{3}$ MD, Getúlio Vargas Hospital, from 1995 to 2003; ${ }^{4}$ Radiologist, São Marcos Hospital, Teresina PI, Brazil.

Received 14 December 2007, received in final form 4 March 2008. Accepted 26 March 2008.

Dr. Manoel Baldoino Leal Filho - Rua Thomaz Tajra 1222 / 300 - 64048-380 Teresina PI - Brasil. E-mail: manoelbaldoino@uol.com.br or manoelbaldoino @gmail.com 
been presenting an incidence of 11.000 new cases a year, most of the cases due to accidents on public roads and physical aggression ${ }^{2}$. The economical impacts in the United States exceed four billion dollars annually ${ }^{5}$.

Although prevention programs have been initiated, there is no evidence that the incidence is in decline ${ }^{3}$. The principal causes of spinal cord injury in Brazil, taking the biggest cities into consideration, are the lesions from firearms, for violent means, and due to traffic accidents ${ }^{6}$. On the other hand, falls, accidents on public roads and diving are seen with certain frequency in the emergency room services ${ }^{7}$.

The city of Teresina, capital city of the State of Piauí, located in the northeast of Brazil and on the eastern border of the Amazonian legal zone has a well recognized health service in the country, due to its quality public health services. The population of the city of Teresina is around 800.000 , while the State of Piaui has around three million inhabitants, but the covering of health care exceeds its borders assisting a population of more than six million people, including patients that arrive from the borders of Brazil with other South American countries. This epidemiological aspect is important due to the long distance the patients have to travel to come to Teresina.

This study has the objective of showing an analysis of some cases of spinal cord injury and to present the principal factors found related to the lesion, especially in those individuals admitted more than four hours after the trauma, most of the time because they had to travel a great distance to arrive at the referred health service.

\section{METHOD}

The present research is a clinical study based on epidemiological and clinical data collected during hospitalization. Three hundred and eighty six patients with spinal cord injury were considered. All of them admitted to a public institution, Getúlio Vargas Hospital, in the city of Teresina, State of Piaui, Brazil that is a reference in terms of health care to a population that exceeds six million inhabitants of Piaui's border, as well as those with other South America countries.
The data were collected over eight years, from January 1995 to December 2002. Participants were evaluated prospectively from the admission to the discharge and the data organized using the Excel ${ }^{\circledR}$ computer program.

All patients were included, victims of trauma and those with spinal lesion due to accidents, operated on or not.

Most of the cases were admitted upwards of four hours after the trauma, some of them were suffering low arterial blood pressure. Therefore, the major goal of the treatment was to expand the effective circulating volume by replacing fluid deficits using crystalloid solution such as Ringer's lactate, saline, as well as correction of hypoxia and acidosis. In those cases, which weren't possible to raise the arterial pressure to the normal level, the insertion of a central venous catheter was a helpful guide for administration of fluids. In some cases, the use of human serum albumin or dopamine was necessary to raise the arterial pressure.

Neurologically the patients were assessed using the Frankel scale ${ }^{8}$ : (A) Severe deficit; (B) Major deficit but deep sensation present; (C) Motor activity, but low function; (D) Partial deficit; (E) Normal.

We certify that all applicable institutional and governmental regulations concerning the ethical use of human volunteers were followed during the course of this research that is a continuation after the Master Thesis published in Arq Neuropsiquiatr in $2002^{9}$. Therefore, the study protocol was approved by the Ethics Committee.

Table 1. Time between the trauma and the admission to the hospital.

\begin{tabular}{ccc}
\hline Time $(\mathrm{h})$ & $\mathrm{n}$ & $\%$ \\
\hline $0-4$ & 81 & 21.0 \\
$4-12$ & 182 & 47.2 \\
$12-24$ & 52 & 13.5 \\
$24-48$ & 26 & 6.7 \\
$\uparrow 48$ & 45 & 11.6 \\
Total & 386 & 100 \\
\hline
\end{tabular}

Table 2. Neurological exam in the admission and at the time of discharge according to the Frankel scale.

\begin{tabular}{ccccc}
\hline Frankel scale & \multicolumn{2}{c}{ Admission } & \multicolumn{3}{c}{ Discharge } \\
\hline & $\mathrm{n}$ & $\%$ & $\mathrm{n}$ & $\%$ \\
$\mathrm{~A}$ & 193 & 50.0 & 120 & 31,1 \\
$\mathrm{~B}$ & 13 & 3.4 & 33 & 8,5 \\
$\mathrm{C}$ & 63 & 16.3 & 63 & 16,3 \\
D & 57 & 14.8 & 55 & 14,2 \\
E & 60 & 15.5 & 69 & 17,9 \\
Death & - & - & 46 & 11,9 \\
Total & 386 & 100 & 386 & 100 \\
\hline
\end{tabular}




\section{RESULTS}

Three hundred and eighty six patients, 333 (86.3\%) male and $53(13.7 \%)$ female were accompanied. One hundred and one (26.2\%) were from the city of Teresina, 117 (30.3\%) came from the others cities in the State of Piaui and $168(43.5 \%)$ were from out of the State, in some cases from $1,000 \mathrm{Km}$ or more away. Thirty seven $(9.6 \%)$ were less than 17 years of age, $326(84.4 \%$ ) were between 18 and 59 years and $23(6 \%)$ were 60 years or older. In relation to the accidents, $148(38.3 \%)$ were due to falls, $85(22 \%)$ automobile related, $46(11.9 \%)$ from firearm, $35(9.1 \%)$ caused by motorcycles, 25 (6.5\%) from diving, 24 (6.2\%) local trauma on the body, 15 (3.9\%) were run over, five (1.3\%) for physical aggression and three $(0.8 \%)$ by knife. The time between the trauma and the admission to the hospital is shown in Table 1. According to the location of the lesion, based on $\mathrm{X}$-rays and computerized tomography and, in some cases, magnetic resonance imaging scan, $197(51 \%)$ were in the cervical column, $104(30 \%)$ in the thoracic and $85(22 \%)$ in the lumbar. The most implicated levels were C5 (80), L1 (50), C6 (42), T12 (39) and C1-C2 (28). In relation to the lesion type, the explosive fracture Denis ${ }^{10}$ II was the most found. The neurological exam in the admission and at the time of discharge, according to the Frankel scale is shown in Table 2. Two hundred and nineteen (56.7\%) individuals underwent surgery and 167 (43.3\%) did not, either because the patients had passed away due to clinical complications or because they did not require surgery. Forty six $(11.9 \%)$ patients passed away due to clinical complications, but just eight (2.1\%) had undergone a surgical procedure, all of them in the cervical level and most of them with respiratory insufficiency. The causes of mortality were: respiratory insufficiency in $37(80.4 \%)$, embolus in three $(6.5 \%)$, sepsis in three $(6.5 \%)$, hyperthermia and arterial pressure imbalance in two (4.3\%) and coronary thrombosis in one $(2.2 \%)$.

\section{DISCUSSION}

Spinal cord injury must be considered among patients after trauma, above all in those with depression of the level of conscience, once the consequences of a damaged spinal cord can be irreparable and result in clinical complications. With the increase in violence everywhere, as well as vehicule accidents traumas happening during domestic activities, at work and leisure, the potential risk for victims of these accidents becomes high ${ }^{2}$. In the present study, there is an agreement with the literature when some epidemiological aspects are considered. There is important evidence that injuries were most commonly sustained in the third decade of life ${ }^{11}$.

Most of the patients were far from the city of Teresina and the most important cause of the injury was falls. In the last few years we can see an increase in the cases of firearms, due to the violence in the cities, despite the law concerning the ban of firearm possession by the civilian population. Considering that about $73 \%$ of the patients were from other cities, we can suppose that this fact was important in terms of the late admission to the hospital (Table 1) and its consequences. Aside from this, it does not seem to have a large influence in terms of mortality (11.9\%), probably due to the health care offered to the patients admitted to the hospital. Based on the results of the literature, 428 accompanied patients from 1982 to 1987, with spinal cord injury, the mortality rate was $21 \%$ and the principal cause of death was breathing inadequacy ${ }^{6}$.

In most of the cases of spinal trauma in humans, the mechanism of the primary lesion is the sharp compression or the laceration of the spinal cord due to the bony displacement or disk herniation, after the fracture-displacement or the fracture-explosion ${ }^{12}$. According to the present study, the place where the trauma occurred had importance in terms of clinical complications. When the cervical level was involved, respiratory problems occurred most of the time, with high risk of death. In patients with spinal cord injuries respiratory complications are still an important cofactor of morbidity and mortality ${ }^{13}$.

There is some biological evidence, based on experimental studies with animals, that if an individual has a spinal cord injury, due to a trauma the early decompression of the spine in the place of the trauma would make neurological improvement possible, although the relevance of this fact for the human beings is still not very clear ${ }^{2}$.

In patients with spinal cord injury, the primary lesion or mechanical trauma rarely causes a total lesion into the spinal cord, even though complete functional loss exists. However, biochemical and pathological alterations into the tissue can worsen after the trauma. To explain this phenomenon, the concept of secondary lesion was developed, in this way justifying numerous mechanisms that have been postulated, giving special emphasis to the vascular mechanism ${ }^{14}$. This could explain the neurological worsening associated to clinical complications.

Despite the large number of investigations regarding treatments, no gold standard therapy for spinal cord injury has been established ${ }^{15}$. International research centers are developing studies on spinal cord injury, aiming to improve rehabilitation-geared interventions and quality of life for patients ${ }^{16}$.

According to our data, $53.4 \%$ of the cases were admitted to the hospital with Frankel A or B, $16.3 \%$ with C and $30.3 \%$ with $D$ or $E$, the mortality rate was $11.9 \%$ and, upon discharge, the patients were $39.6 \%$ with $A$ or $B, 16.3 \%$ with $\mathrm{C}$ and $32.1 \%$, D or $\mathrm{E}$ (Table 2). Among them, there were 
those cases that underwent surgery (56.7\%), but just $2.1 \%$ passed away due to clinical complications.

During the present study, from 1995 to 2002, we had used the Frankel scale because our study had begun before 1997, but currently we have been using the ASIA/IMSOP Scales of International Standards ${ }^{17}$.

This study shows how patients admitted more than four hours after the trauma can follow up despite clinical complications due to secondary lesions. In terms of medical care, we emphasize the importance of the expansion of the effective circulating volume and the correction of hypoxia and acidosis.

\section{REFERENCES}

1. Foulkes MA, Eisenberg HM, Jane JA, Marmarou A, Marshall LF. Traumatic Coma Data Bank Research Group. The traumatic coma data bank: design, methods and baseline characteristics. J Neurosurg 1991;75(Suppl): S8-S13.

2. Fehlings MG, Tator $\mathrm{CH}$. An evidence-based review of decompressive surgery in acute spinal cord injury: rationale, indications, and timing based on experimental and clinical studies. J Neurosurg (Spine 1) 1999;91:1-11.

3. Taoka Y, Okagima K. Spinal cord injury in the rat. Prog Neurobiol 1998;56:341-358.

4. Kraus JF, Franti CE, Riggins RS. Incidence of traumatic spinal cord. J Chronic Dis 1975;28:471-492.

5. Stripling TE. The cost of spinal cord injury: the economic consequences of traumatic spinal cord injury. Paraplegia News August 1990;50-54.
6. Barros TE Filho, Taricco MA, Oliveira RP, Greve JM, Santos LC, Napoli MM. Epidemiological study of patients with spinal cord injuries and neurological deficit admitted to the Institute of Orthopedics and Traumatology at the Hospital das Clínicas - School of Medicine of the University of São Paulo. Rev Hosp Clin Fac Med São Paulo 1990;45:123-126.

7. Leal MB Filho, Borges G, Silva BB, Almeida BR. Contribution to the surgical treatment of patients with cervical spinal cord injury using simple procedures. Trop Doctor 2003;33:13-14.

8. Frankel F, Hancock DO, Hyslop G et al. The value of postural reduction in the initial management of closed injuries of the spine with paraplegia and tetraplegia. I. Paraplegia 1969;7:179-192.

9. Leal MB Filho. Surgical treatment of patients with cervical spinal cord injury by anterior approach using bone graft (Abstract). Thesis. Arq Neuropsiquiatr 2002;60:179.

10. Denis F. Spinal instability as defined by the three-column spine concept in acute spinal trauma. Clin Orthop Relat Res 1984;189:65-76.

11. Herculano MA, Tella OI Jr, Bonatelli APF. Surgical treatment of the traumatic lesions of medium inferior segment of cervical column. Arq Neuropsiquiatr 2000;58:656-663.

12. Tator $\mathrm{CH}$. Spine-spinal cord relationships in spine cord trauma. Clin Neurosurg 1983;30:479-494.

13. Leal MB Filho, Morandin RC, Almeida AR, et al. Hemodynamic parameters and neurogenic pulmonary edema following spinal cord injury: an experimental model. Arq Neuropsiquiatr 2005;63:990-996.

14. Tator $\mathrm{CH}$, Fehlings MG. Review of the secondary injury theory of acute spinal cord trauma with emphasis on vascular mechanisms. J Neurosurg 1991;75:15-26.

15. Baptiste DC, Fehlings MG. Pharmacological approaches to repair the injured spinal cord. J Neurotrauma 2006;23:318-334.

16. Pereira MEMSM, Araújo TC. Coping strategies in rehabilitation of spinal cord injury. Arq Neuropsiquiatr 2005;63:502-507.

17. Maynard FM Jr, Bracken MB, Creasey G, et al. International standards for neurological and functional classification of spinal cord injury. American Spinal Injury Association. Spinal Cord 1997;35:266-274. 